\title{
Study on Oil Displacement Efficiency of Binary Compound Flooding in Heterogeneous Reservoir
}

\author{
Zhenzhong Fan', Meng Wang1, Jigang Wang1, Xin Wang' \\ ${ }^{1}$ EOR Key Laboratory of the Ministry of Education, Northeast Petroleum University, Daqing, China \\ ${ }^{2}$ Liaohe Oilfield Drilling Technology Research Institute, Panjin, China \\ Email: fanzhenzhong@163.com,610538383@qq.com, wangxin19880529@163.com, 253769510@qq.com
}

Received 23 October 2015; accepted 16 November 2015; published 19 November 2015

Copyright (C) 2015 by authors and Scientific Research Publishing Inc.

This work is licensed under the Creative Commons Attribution International License (CC BY). http://creativecommons.org/licenses/by/4.0/

(c) (i) Open Access

\begin{abstract}
Heterogeneous reservoir characteristics for oilfield, choose HS-1 non-ionic surfactant and polymer formation in binary combination flooding system can significantly improve the rate of production of low permeability reservoir in heterogeneous reservoir. According to the core flooding experiment analyzed longitudinal heterogeneous models, single surfactant and a single polymer and polymer flooding of table binary complex drive effect. Studies show that binary combination flooding recovery effect is best, followed by polymer flooding, minimum of surfactant flooding, in heterogeneous reservoir.
\end{abstract}

\section{Keywords}

Heterogeneous Reservoir, Binary Compound Flooding, Oil Displacement Efficiency

\section{Introduction}

With reservoir into high containing water development late, it has a big part crude oil stranded in the reservoir. Its reasons are these reservoirs which have more reservoirs and layers between different, big, and pore structure complex and features. The heterogeneity of reservoir makes the injected water main along high permeable layer flooding in the secondary oil recovery. Hard mining in the low penetration rate reservoir leads to crude oil stranded in the low penetration reservoir [1] [2]. Therefore, screening for flooding in heterogeneous reservoir for EOR technology is of great significance. In EOR techniques, the main method is surfactant flooding and polymer flooding. The surfactant flooding is usually improved by improving oil displacement efficiency of oil recovery, and polymer flooding is by improving the flow ratio, reducing water fingering, and 
increasing the swept volume to improve recovery rates [3]. Both methods alone cannot meet the needs of heterogeneous reservoir exploitation, so it is necessary to study on binary combination flooding of polymer/surfactant [4].

\section{Experimental Materials and Equipment}

Polymer: Daqing refining of company production of part hydrolysis polypropylene $\mathrm{n}$ amine, molecular volume $2500 \times 104$; surfactant: non-ion surfactant HS-1; experiment water: indoor configuration of simulation formation water, total salinity for $2010 \mathrm{mg} / \mathrm{L}$; artificial are quality rock heart, size for $45 \times 45 \times 3000 \mathrm{~mm}$ specific data in Table 1; experiment in the used simulation oil, by oilfield dehydration crude oil added a quantitative by filter of refined white oil diluted, to must proportion for mixed distribution into simulation oil, determination of viscosity of $25.6 \mathrm{~m} \mathrm{~Pa}$. s $\left(50^{\circ} \mathrm{C}\right)$, oilfield injection water.

\section{Determination of Binary Complex Drive System Performance}

\subsection{Determination of Interfacial Tension}

Oilfield sewage configuration of polymer concentration as $1000 \mathrm{mg} / \mathrm{l}$, different HS-1 surfactant concentration of binary systems, at $50^{\circ} \mathrm{C}$ temperature determination using TX-500C spinning drop Interfacial tensiometer under binary system of Daqing crude oil Interfacial tension. Results are shown in Figure 1.

Figure 1 shows that, when surfactant concentration is above $0.05 \%$, binary complex drive system and number of Daqing crude oil Interfacial tension to reach $10^{-3}$ level, with good interface activity. When surfactant concentration is $0.05 \%$, HS- 1 binary surfactant systems the Interfacial tension values for $5.0 \times 10^{-3} \mathrm{mN} / \mathrm{m}, 10^{-3}$ order, HS-1 high efficiency of surfactants reduces Interfacial tension. Adsorption loss, taking into account the formation of oil displacement agent costs and other factors, evaluation of oil displacement when surfactant concentration is $0.5 \%$.

\subsection{Determination of Interfacial Tension Stability}

Chemical flooding, flooding from injected into the formation to pick out, under the influence of spacing and

Table 1. Drill core parameter of experiment.

\begin{tabular}{cccc}
\hline Drill core & Length $(\mathrm{cm})$ & Effective sectional area $\left(\mathrm{cm}^{2}\right)$ & Air permeability $(\mathrm{md})$ \\
\hline high-permeability drill core a-1 & 30.08 & 19.72 & 346 \\
high-permeability drill core a-2 & 30.09 & 19.80 & 325 \\
high-permeability drill core a-3 & 30.15 & 19.64 & 307 \\
low-permeability drill core b-1 & 30.17 & 19.71 & 50 \\
low-permeability drill core b-2 & 30.18 & 19.71 & 48 \\
low-permeability drill core b-3 & 30.20 & 52 \\
\hline
\end{tabular}

Air permeability testing instrument: United States core produced by gas permeability measurement instrument.

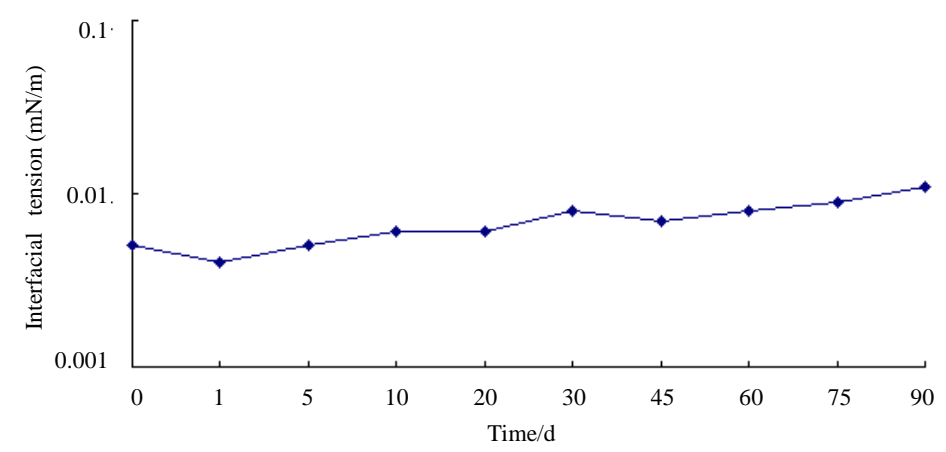

Figure 1. Variation of Interfacial tension for binary systems with surfactant concentration curve. 
formation conditions, migration time of need in the underground, this requires maintaining ultra-low Interfacial tension for a long time. Oilfield sewage configuration of polymer concentration as $1000 \mathrm{mg} / \mathrm{l}$ surfactant concentration of $500 \mathrm{mg} / \mathrm{l}$, HS- 1 of binary systems, at $50^{\circ} \mathrm{C}$ temperature determination using TX-500C spinning drop Interfacial tensiometer under binary system of Daqing crude oil Interfacial tension. Results are shown in Figure 2.

Figure 2 shows that, within 90 days of the measure, Interfacial tension for binary systems increased slightly, but remain at low Interfacial tension range meet the requirements for stability of Interfacial tension of surfactant.

\subsection{Emulsifying Capacity Determination}

Commonly used in macro-analysis on the stability of emulsion method for determination of water and observed under certain temperature emulsion of water, on the water, indicating stable emulsions. Conversely, if stated on the water emulsion instability. Daqing crude oil and mix in 1:1 of binary systems, into a colorimetric tube at $50^{\circ} \mathrm{C}$ temperature shocks, fully static observed time on the water, determine the system's water rates change over time. Results are shown in Figure 3.

Figure 3 shows that emulsified temperature $1 \mathrm{~h}$ of binary systems, systems of water is $12.5 \%$, but with the extension of when asked, sweating rate rising fast; when asked when placing more than $24 \mathrm{~h}$, the water rates rise slowly, $5 \mathrm{~d}$ system of water rate reaches a maximum, indicating that emulsion ability of binary systems.

\section{Indoor Flooding Experiment}

This experiment using high permeability cores with flooding of low permeability cores in parallel to study the system in heterogeneous reservoir in the recovery. Concentration of single polymer systems: $1000 \mathrm{mg} / \mathrm{L}$, single concentration of surfactant system for $500 \mathrm{mg} / \mathrm{L}$. Polymer concentration in binary combination flooding system for $1000 \mathrm{mg} / \mathrm{L}$, surfactant concentration is $500 \mathrm{mg} / \mathrm{L} \mathrm{[5]} \mathrm{[6].}$

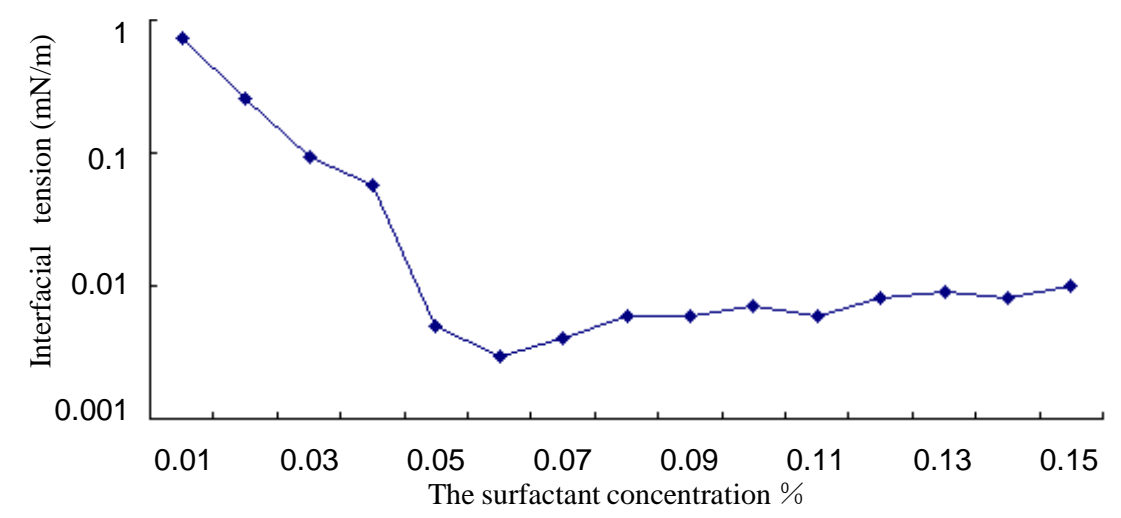

Figure 2. Curves of Interfacial tension for binary systems-time.

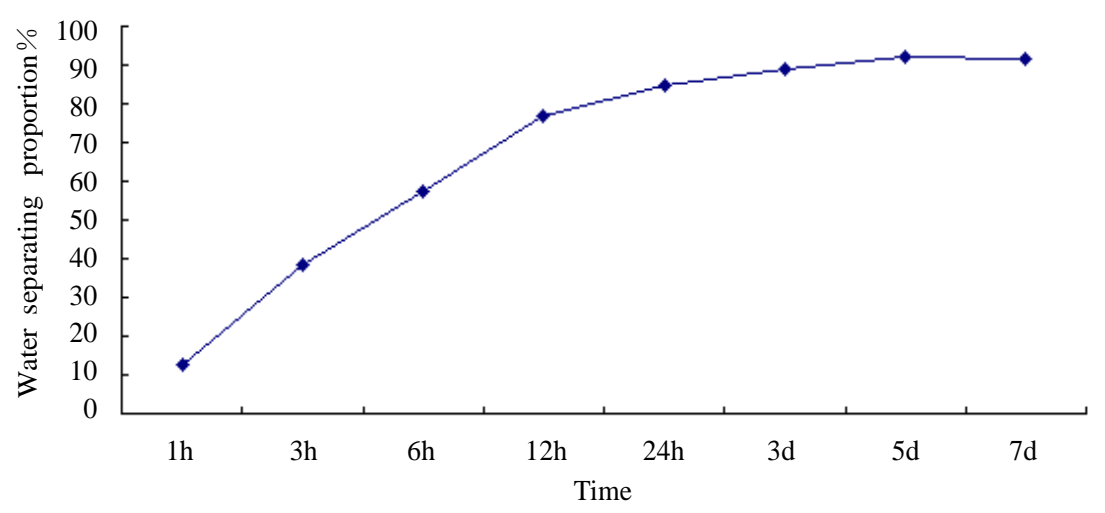

Figure 3. Binary system of emulsified water rate curves. 
Table 2. Flooding results table.

\begin{tabular}{|c|c|c|c|c|c|c|c|c|}
\hline $\begin{array}{c}\text { Cores } \\
\text { number }\end{array}$ & $\begin{array}{c}\text { Experiment } \\
\text { scheme }\end{array}$ & $\begin{array}{l}\text { Pore } \\
\text { volume } \\
\text { (ml) }\end{array}$ & $\begin{array}{l}\text { Saturation } \\
\text { of oil (\%) }\end{array}$ & $\begin{array}{c}\text { Water } \\
\text { flooding } \\
\text { recovery (\%) }\end{array}$ & $\begin{array}{c}\text { Chemical } \\
\text { flooding } \\
\text { recovery (\%) }\end{array}$ & $\begin{array}{l}\text { Total } \\
\text { recovery } \\
(\%)\end{array}$ & $\begin{array}{l}\text { Flooding } \\
\text { program } \\
\text { recovery (\%) }\end{array}$ & $\begin{array}{l}\text { Enhanced oil } \\
\text { recovery (\%) }\end{array}$ \\
\hline$a-1$ & \multirow[b]{2}{*}{ Polymer } & 150.6 & 72.3 & 38.5 & 9.6 & 48.1 & \multirow[b]{2}{*}{44.5} & \multirow[b]{2}{*}{14.3} \\
\hline$a-2$ & & 123.2 & 67.5 & 19.3 & 20.5 & 39.8 & & \\
\hline a-3 & \multirow{2}{*}{ Surfactants } & 148.5 & 70.5 & 37.1 & 12.6 & 49.7 & \multirow{2}{*}{38.6} & \multirow{2}{*}{8.9} \\
\hline b-1 & & 125.6 & 68.2 & 20.6 & 4.5 & 25.1 & & \\
\hline b-2 & \multirow{2}{*}{$\begin{array}{c}\text { Binary } \\
\text { compound } \\
\text { flooding }\end{array}$} & 153.0 & 71.6 & 39.5 & 19.3 & 53.8 & \multirow{2}{*}{50.7} & \multirow{2}{*}{19.3} \\
\hline$b-3$ & & 125.5 & 68.2 & 21.0 & 26.0 & 47.0 & & \\
\hline
\end{tabular}

\section{Experiment Results and Discussion}

In Table 2, we can see: end of the water flooding recovery of high permeability rate of low-permeability rock recovery; polymer drive oil can significantly improve low penetration rock heart of harvest rate, surfactant drive oil on high penetration rock heart of harvest rate effect larger, binary compound flooding system for high and low permeability rock is the recovery will have a greater impact. Polymer, surfactant and binary compound flooding system can enhance overall recovery in varying degrees, binary compound flooding enhancing oil recovery and gathering tables (19.3), polymer then (14.3), minimum of surfactant (8.9).

\section{Conclusions}

1) When HS-1 surfactant concentration is more than $0.05 \%$, interfacial tension values of the binary compound drive system at $10^{-3}$ by orders of magnitude.

2) Stability of surfactant HS-1 interfacial tensions of binary systems can be up to 60 days; oil-water ratio 1:1, after seven days of binary system, emulsified water is $91.4 \%$.

3) In a non-homogeneous core flooding experiment, poly table than a single binary combination flooding system of surfactant and oil recovery enhances the value of a single polymer and best adaptability of binary combination flooding system to heterogeneous reservoirs followed by polymer. Surfactant is the worst.

4) With the majority of oil into the oilfield development in the late, binary flooding system on the status of heterogeneous reservoirs will be more prominent.

\section{Acknowledgements}

The project is supported by Heilongjiang Province Natural Science Foundation of Cationic Gemini Surfactant Study of Oil Displacement Technique. Fund No: E201337.

\section{References}

[1] Wu, W.X., Zhang, Y.X., Ma, J.Q., et al. (1999) With Different Relative Molecular Weight of Polymer Oil Displacement Effect of Injecting Order. Journal of Daqing Petroleum Institute, 23, 15-19.

[2] Chen, Q.F., Jiang, J.L. and Luo, X.Y. (2008) Central Binary Surfactant/Oil Field Polymer Flooding Laboratory Study. Oil Field Chemistry, 25, 77-81.

[3] Gang, Y.H., He, H., Hu, L., et al. (2010) Binary Combination Flooding Enhancing Oil Recovery Technology Development. Oil Gas Field Surface Engineering, 012, 61-62.

[4] Fukuoka, Y., Haruyuki, H.M. (1998) A Modified Back Propagation Method to Avoid False Local Minima. Neural Networks, 13, 1059-1072. http://dx.doi.org/10.1016/S0893-6080(98)00087-2

[5] Zekri, A.Y. and Jerbi, K.K. (2002) Economic Evaluation of Enhanced Oil Recovery. Oil \& Gas Science and Technology, 57, 259-267. http://dx.doi.org/10.2516/ogst:2002018

[6] Cui, Z. and Zhu, Y.D. (2013) Heavy Oilfield Research Progress of Chemical Flooding for EOR. Petrochemical in Inner Mongolia, 39, 153-156. 